\title{
REPUBLIKANIZMUS: A MIGRÁCIÓ EGY LEHETSÉGES ÉRTELMEZÉSE?*
}

\author{
Ujlaki Anna \\ (BCE Politikatudományi Doktori Iskola)
}

A tanulmány beérkezett: 2020. január 9. - opponálás: 2020. január 14.- január 31. - véglegesítve: 2020. február 15.

ÖSSZEFOGLALÓ

\begin{abstract}
A migráció témáját sokan az évezred legégetőbb kérdései egyikének tekintik. A politikaelméletnek lényeges szerepe van a migráció kapcsán felmerülő kérdések megfelelő értelmezésében, illetve az azokra adott válaszok megfogalmazásában. A migráció politikaelmélete azonban gyakran olyan előfeltevéseken alapul, amelyek megakadályozzák egy szisztematikus és cselekvést irányító megközelítés létrejöttét. A tanulmány Philip Pettit republikánus politikaelméletének négy olyan elemét azonosítja, amelyek révén a migráció új szempontok alapján is vizsgálhatóvá válik, és amelyek lehetôvé teszik a migráns személyek által a valóságban elszenvedett igazságtalanságok, illetve a migrációt szabályozó politikai cselekvés kritikus szemmel történő vizsgálatát. A tanulmány rámutat, hogy a republikanizmus potenciálja nem mutatkozik meg Pettitnek a migrációra vonatkozó elképzeléseiben, aki ezekben inkább reprodukálja a mainstream megközelítések előfeltevéseit.
\end{abstract}

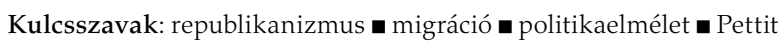

Noha a migráció története egyidős az emberrel, a jelenség mégis csupán az elmúlt néhány évtizedben került a tudományos érdeklődés látóterébe. A migráció azok közé a témák közé tartozik, amelyek a modern világ kihívásaként fogalmazódnak meg, illetve amelyek mentén gyakran megosztó álláspontok születnek. Érdekes módon azonban úgy tûnik, a politikaelmélet egyelőre nem volt képes ezeket a közvélekedéseket a téma pontos és átfogó vizsgálataival ellensúlyozni. Bár a migráció politikaelméletérôl egyre több írás születik, a szakirodalom legnagyobb részét a bevándorlás korlátozásának kérdésérôl és az emberi jogokról diskurzust folytató domináns liberális politikai filozófia teszi ki, pedig a jelenség ezeknél a kérdésnél sokkal komplexebb, ráadásul jóval több normatív implikációt von maga után.

* A tanulmány az MTA TK Politikatudományi Intézet Alkotói Pályázata keretében készült. 
A migráció alapos politikaelméleti kutatásának igénye rendkívüli gyakorlati jelentőséggel bír. Egyrészt a tudományos igényesség szempontjából elengedhetetlen, hogy a politikaelmélet megfelelően keretezze a jelenséget, emellett kimerítően foglalkozzon a téma tekintetében felmerülő kérdésekkel és a migráció egyes vonatkozásaival. Másrészt a politikaelmélet és a politikatudomány presztízsének szempontjából is fontos, hogy megcáfolja azokat a kritikákat, amelyek szerint a politikáról való tudományos gondolkodás nem képes irányt mutatni a társadalmi és gazdasági kihívásokkal szemben, így elkerülhetetlen feladat, hogy létrejöjjön a migrációval kapcsolatos elképzelések egy alaposabb és gazdagabb politikaelmélete, amely megfelelő eszköztárat biztosít nemcsak a tudományos érdeklődés, de a gyakorlati politika és a mindennapi élet számára is.

A tanulmány célja, hogy megvizsgálja, mennyiben jelenthet alternatívát a migráció domináns megközelítéseivel szemben a kortárs republikánus politikaelmélet. Az irányzat legszisztematikusabb elméletét kidolgozó Philip Pettithez köthető republikanizmus sokak szerint komoly kihívója a John Rawls nyomán teret hódító liberális politikai filozófiának. Ezért kézenfekvő a kérdés, hogy a republikanizmus megoldást jelenthet-e a domináns politikaelmélet migrációval kapcsolatos problémáira. A kérdés azért is érdekes, mert bár Pettit nagyobb múveit a Rawlséhoz hasonló szisztematikusság dicséretével lehet illetni, fő munkáikon belül egyikük sem adózott komolyabban a migráció kérdésének, mindeközben a Rawls utáni, a migráció politikaelméletéről szóló szakirodalom inkább csak egyes, a jelenséggel kapcsolatos népszerü témákra koncentrál. A tanulmányban beazonosítom a neorepublikanizmus négy olyan jellegzetességét, amelyek miatt ez a politikaelméleti irány sikeresebb lehet a migráció egy pontosabb és gazdagabb megközelítésének megalkotására. Bemutatom, hogy bár ezek potenciális eszközök lehetnének a domináns politikaelmélet nehézségeinek meghaladására, mégsem jelennek meg Pettitnek a migrációval és mobilitással kapcsolatos elképzeléseiben, aki pont ebben a témában, így a nemzetközi viszonyokról való elképzeléseiben és a nemzetközi témáknak a társadalom "belső" kérdéseitől való éles elválasztásában bevallottan épít Rawlsra. Ebből fakadóan a migráció szempontjából Pettit politikaelmélete éppen azokban a kérdésekben nem tudja meghaladni a kihívott irányzatot, amelyekben elméleti (és ebből fakadóan gyakorlati) szempontból sikeresebb lehetne annál.

A tanulmány a következőképpen épül fel. Az első fejezetben bemutatom, milyen módon jelenik meg a migráció a politikaelméletben, mik a téma fóbb megközelítési irányai, valamint rámutatok, milyen kihívások miatt tekinthető elégtelennek a meglévő szakirodalom. A második fejezetben megfogalmazom azt a négy adottságot, amelyek alkalmassá teszik a republikánus politikaelméletet, hogy alternatíváját jelentse a témáról alkotott liberális elképzeléseknek, itt utalok azokra a témákra, amelyeket a republikánus szemlélet felvethet, illetve amelyeket egyes szerzők már tárgyaltak. A harmadik fejezetben rámu- 
tatok, hogy a republikanizmusban meglevő lehetőségek ellenére Pettit mégis a rawlsi eszköztárhoz nyúl vissza a migrációról és mobilitásról való elképzeléseinek megfogalmazásakor. Végül pedig levonom a következtetéseket a migráció politikaelméletére vonatkozóan.

\section{MIGRÁCIÓ ÉS POLITIKAELMÉLET}

Kevés kétség fér ahhoz, hogy az emberiség történetének inherens része egyes emberek és kisebb vagy épp nagyobb embercsoportok egy területről egy másikra való rövid- vagy hosszútávú, esetleg ciklikus vándorlása. Bár az adott terület földrajzi és éghajlati tényezői, illetve a társadalmi-politikai körülmények mindig is nagyban meghatározták ennek az emberi vándorlásnak a jellegét, amelyre a történelem folyamán számos ok és forma volt jellemző, öszszességében elmondható, hogy az ember mobilis lény.

Hogyan fordulhat mégis elő, hogy a politikaelmélet leghíresebb múveiben a migráció kérdése alig vagy mellékesen merül csak fel? Az egyik magyarázat talán az lehet, hogy a politikáról való gondolkodás híveit már az antik szerzők óta a politikai közösség számos, az emberek mozgásánál érdekesebb kérdés foglalkoztatja. Az is indokot adhat a téma gyakori nélkülözésére, hogy a modern világ alapvetően államokból épül fel, így a modern tudományos kutatás (amely nem mellékesen legtöbbször nemzeti tudományos akadémiákon folyik) kézenfekvő módon a statikusnak tekintett államokra fordítja a figyelmét. Így megeshet, hogy egyrészt az emberi mozgás néhány dimenziója, mint amilyen az államon belüli vándorlás, egyszerúen ne bírjon lényeges tartalommal még a politika és a közösség legszisztematikusabb elméletei számára sem, másrészt mindennemú határon átívelö migráció csupán esetleges hibaként, patologikusan bukkanjon fel a politikaelmélet számos múvelője előtt.

Egy lehetséges érv a migráció témájának ilyen mértékû nélkülözésére az lehet, hogy a szerzőknek egyszerúen nem célja az emberi mozgás kérdéseinek vizsgálata. Igazságosságról, egyenlőségről, szabadságról, jogokról és kötelezettségekről, demokráciáról vagy rezsimekről általában, de akár állampolgárságról és pluralizmusról is lehetséges vitákat folytatni anélkül, hogy különösebb jelentőséget tulajdonítanánk közben a migrációnak vagy a mobilitásnak. Ettől függetlenül azonban az elmúlt néhány évtizedben határozott igény jelent meg a migráció egyes témáinak alapos, átfogó politikaelméleti megközelítéseire, azaz a migráció politikaelméletére. A következőkben bemutatom, hogyan jelent meg és formálódott egészen napjainkig ez a terület, illetve milyen jellegzetességei és hiányosságai fedezhetők fel. Ezek fényében vélhetően érthetővé válik, miért merül fel a kérdés, hogy az egészen újonnan előtérbe kerülő kortárs republikánus politikaelmélet esetleg egy megfelelőbb értelmezését kínálhatja-e a témának. 
Az angol nyelvű normatív politikaelméletet az 1970-es évektől John Rawls munkássága határozta meg (elsősorban Rawls, 1997 [1970]; 2005 [1993]). Rawls elgondolásai közül több máig fontos része a diszciplína eszközkészletének, másokat pedig tekintélyes vita kísér. Ezek mellett azonban vannak olyan rawlsi elképzelések, amelyek hatására akkor derül fény, amikor a politikatudomány vizsgálódási körét igyekszünk kiterjeszteni eddig kevésbé vizsgált területekre is, mint amilyen az emberi vándorlás és mobilitás témája.

Bár Rawls több kritikusa felhívta a figyelmet arra, hogy a társadalmi igazságosság elmélete a társadalmat zárt rendszerként leíró jellege miatt a valódi világ számos fontos elemét, így több igazságtalan és elnyomó jelenségét is figyelmen kívül hagyja, a rawlsi politikai filozófia számos alapkoncepciója kritika nélkül él tovább a főáramú politikaelméletben, és kihat a migráció témájának megközelítéseire. Ilyen például az elemzés alapvető egységének tekintett egymástól elszeparált, autonóm társadalmak képe, amelyet Rawls a kései, nemzetközi viszonyokról szóló elméletében is fenntart (Rawls, 2008 [2001]). Emellett továbbra is jellemző ehhez a társadalomhoz homogén kultúrát és kötött tagságot társítani (Sager, 2018: 18.; 28.; 2016). A tudományos vizsgálódás szempontjából kétségtelenül megvannak a maga előnyei ezeknek az előfeltevéseknek, amelyeket nem csupán a politikaelmélet, de az empirikus politikatudomány is gyakran használ (Sager, 2018: 22.; Beck, 2002: 51.; Wimmer-Glick Schiller, 2002: 306-307.). Azonban az előfeltevések kritika nélküli használata számos tekintetben torzítja a politikaelmélet valóságról alkotott képét, kifejezetten olyan kérdésekben, amelyek esetén lényeges volna a jelenségek pontos leírása és az önreflexió. Ezeket a bírálatokat az elmúlt két évtizedben a társadalomtudományokban paradigmaváltást sürgető szerzők a módszertani nacionalizmus kritikájaként foglalták össze (Beck, 2000; Wimmer-Glick Schiller, 2002; 2003; Sager, 2016; 2018).

A politikatudomány egyes előfeltevéseinek problémái akkor válnak igazán szembetûnővé, amikor olyan témák merülnek fel, mint a migráció. Azok az elképzelések és modellek, amelyek alkalmasak egy társadalomban felmerülő belső (domestic) ügyek elméleti vizsgálatához, elégtelenek a migráció szisztematikus és konzisztens politikaelméletének megalkotására. A migráció kortárs politikaelméletére gyakran láthatóan a társadalomról való politikai és filozófiai gondolkodás kiegészítéseként tekintenek a politikaelmélet múvelői, így az egyébként sokrétű téma igencsak redukált formájában jelenik meg a szakirodalomban. Ez elsősorban azt jelenti, hogy a meghatározott területtel és tagsággal bíró politikai közösséghez képest, amellyel kapcsolatban a politikai filozófusok hajlamosak a mozdulatlanság illúziójával élni, anomáliaként jelennek meg azok az egyének és csoportok, amelyek valamilyen okból államhatárokon is átlépnek, hogy többé-kevésbé hosszabb ideig az ôket fogadó állam területén dolgozzanak, letelepedjenek, vagy akár állampolgárságért folyamodjanak (Nail, 2015: 3-5.; 13; Sager, 2016: 50.; 2018: 3.; 20; 25.). Bár emellett egyébként meg- 
jelenik a kényszerített migráció is a szakirodalomban, elsősorban a menekültek kérdése és az emberi jogok kapcsán (míg például az emberkereskedelem és a lakóhely elhagyásának egyéb kényszerített formái kevés figyelmet kapnak), a téma szerzői szinte kizárólag a fogadó állam szemszögéből fellelhető dilemmákról folytatnak vitákat. Így mondható el összességében, hogy a migráció meghatározó, liberális politikaelméletének és etikájának diszkusszióját mindenekelőtt a határok és a bevándorlás korlátozásának kérdése uralja (Sager, 2016 és 2018; vö. Abizadeh, 2008 és 2010; 2016; Blake, 2013 és 2014; Carens, 1987 és 2013; Fine, 2016; Miller, 2016a és 2016b; Oberman, 2016; Sager, 2017; Shachar, 2016; Wellman, 2016).

A szakirodalomra az is jellemző, hogy a migráció kérdései a (zártnak tekintett) társadalom politikaelméletétől függetlenül, a nemzetközi viszonyok problémájaként merülnek fel. A politikatudományi vizsgálódás ilyen fokú felosztása belső és külső ügyekre - ha úgy tetszik egy belső és egy külső világra - téves dichotómia (Sager, 2018: 45-48.). A felosztás egyrészt azon a feltevésen alapszik, hogy a nemzetek és a nemzetközi viszonyok világa között a politikai közösség stabil külső határa jelent elválasztást, másrészt ez a határ csak territoriális értelemben létezik (vagy legalábbis minden más típusú határ egybeesik azzal), harmadrészt a határellenőrzés, így a társadalom területére való bebocsátás elbírálása az államnak ezen a területi határán történik (Balibar, 2002: 75-79; Sager 2018: 47.). Ezek az implicit feltevések megakadályozzák olyan szisztematikus politikaelméleti múvek megalkotását, amelyek egyaránt figyelmet fordítanának a globális jelenségekre, az államhatárokon átnyúló komplex viszonyokra, a transznacionális szereplőkre, az egyénekre ható különféle tényezőkre és az őket érő igazságtalanságokra.

A globális szemlélet hiánya hatással van a politikaelmélet (és egyébként az empirikus politikatudomány) presztízsére is. Az államon belüli, és a határokon átnyúló migrációról, valamint az államhatárok jellegéről nagymértékben pontatlan és sematikus képet nyújtó, a Rawls nyomán meghatározóvá váló liberális politikaelmélet egyrészt azt a benyomást keltheti, hogy a témában a politikaelmélet múvelői nem képesek a globális jelenségeket és kihívásokat megfelelően anticipálni. Másrészt létjogosultságot adhat azoknak a kritikáknak, amelyek szerint a fóáramú politikaelmélet semmiféle útmutatást nem képes adni a modern világban való cselekvéshez (vö. Sager, 2018: 76.; Valentini, 2012).

A migráció témája Joseph Carens 1987-es Aliens and Citizens címú írásával bukkant fel a politikaelmélet fősodrában. ${ }^{1}$ A tanulmányban az volt a meghökkentő, hogy abban Carens nem kizárólag a maga részérôl érvelt a nyitott határok mellett, hanem rámutatott, hogy valamennyi fontos kortárs politikaelmélet (ez alatt a rawlsi, a nozicki és a haszonelvú irányzatot értette) továbbgondolása esetén kizárólag a bevándorlók előtti nyílt határok lennének igazolhatók (Carens, 1987). A Carens álláspontjára érkező válaszok, bár számos különbö- 
ző irányból érkeztek, abban hasonlítottak, hogy igyekeztek különböző érvekkel igazolni, hogy az államnak diszkrecionális joga van a saját határai felett, amiket bizonyos emberek előtt zárva tarthat (például Miller, 2005, 2010 és 2016b; Wellman, 2008 és 2016; Blake, 2013).

A vita szubsztantív elemzésétől ezúttal eltekintve inkább arra kívánok rámutatni, hogy a migráció politikaelmélete - beleértve a kozmopolitizmus egyes formáit ${ }^{2}$ - láthatóan megragadt a kezdeti nyitott kontra zárt határok vita keretei között, arra a kérdésre keresve a választ, hogy az államok (többnyire a fejlett, nyugati liberális demokráciák) milyen kötelezettségekkel bírnak a bevándorlók befogadásának tekintetében (Sager, 2018: 25-26.; vö. Wilcox, 2009). Így a migrációról szóló kötetek legnagyobb része valójában a bevándorlás etikájáról szól (például Carens, 2013; Cole, 2000; Fine-Ypi 2016; Miller, 2016a; Pevnick, 2014; Wellman-Cole, 2011). Csupán az elmúlt pár évben jelentek meg olyan kötetek, amelyek interdiszciplinárisabb alapokra építve, a migrációs tanulmányok, a szociológia, az antropológia, valamint a történettudomány eszközeit ötvözve a migráció politikaelméletének egy a módszertani nacionalizmus előfeltevéseitől megszabadított, a migráns személyek, a „kívülállók”, illetve a mozgás szemszögéből értelmezett megközelítését szorgalmazzák (ilyen Nail, 2015; Sager, 2018).

A migráció alternatív vizsgálatára azonban nem csak radikális, interdiszciplináris alapokon álló álláspontról van lehetőség. A diszciplínán belüli politikaelméleti irányzatok gazdag eszköztárat nyújthatnak a migráció egy pontos és átfogóbb politikaelméletének megalkotásához. Az elmúlt néhány évben újjászületô republikánus politikaelmélet potenciálja a kérdésben megkérdőjelezhetetlen, már csak azért is, mert elsősorban a Philip Pettit nevéhez köthető, neorepublikánusnak nevezett politikaelméletet követő szerzők egy-egy republikánus elképzelésre építve már számos, a migrációhoz kapcsolódó kérdéshez hozzászóltak. A következő fejezetben bemutatom, miért kézenfekvő a kortárs republikanizmus a migráció alternatív megközelítésének vizsgálatára.

\section{REPUBLIKANIZMUS, MINT KÉZENFEKVŐ ALTERNATÍVA}

A republikanizmus reneszánsza az elmúlt néhány évtizedben a republikánus tradíció témáinak és fogalmainak újraéledését jelentette. Ez annak köszönhetô, hogy előbb néhány szerző felelevenítette a republikanizmus antik elképzeléseit és rámutatott azok visszatérésére a későbbi korokban; majd pedig a republikánus tradícióra alapozva a normatív politikaelmélet néhány múvelőjének közremúködésével kialakult a kortárs republikánus politikaelmélet. Ezek a szerzők egyrészt republikánus alapokon kritizálják a domináns liberális politikaelméletet, másrészt pedig szubsztantív állításokat fogalmaznak meg a politikai közösségről. Az irányzat mellett több neves szerző foglalt állást (köztük 
Bohman, 2007; Honohan, 2002; Honohan-Jennings, 2015; Laborde, 2008; Laborde-Maynor, 2008; Lovett, 2010 és 2016; Lovett-Pettit, 2009; Martí-Pettit, 2010; Pettit, 1996 és 2002 [1997]; 2012a, 2012b és 2014; Skinner, 1997, 2002, 2008 és 2010; Viroli, 1995; Weinstock-Nadeau, 2012), közülük azonban Pettit eredetileg 1997-ben kiadott Republicanism (2002) címú kötete a legszisztematikusabb munka, amelyre a kortársak részéről hivatkozni szokás.

A Pettit-féle polgári (civic) republikanizmus vagy neorepublikanizmus eltér a gyakran szintén republikánusnak nevezett kommunitárius megközelítésektôl (például Sandel, 1998), lényege pedig a szabadság sajátos értelmezésében áll (Honohan, 2002: 8.; Lovett-Pettit, 2009: 12-13.). Pettit a republikanizmus esszenciáját a politikai szabadság ideáljában látja, amelyet az uralomtól való mentességként (non-domination) definiál. A szabadságnak ez az értelmezése egy olyan állapotot takar, amelyben az egyén nagymértékben élvez immunitást mások önkényes hatalmával szemben (Pettit, 2002: vii-viii., 5., 22. és 52.). Pettit ebben a szabadságfogalomban látja a republikanizmus alapvető különbségét a liberalizmussal szemben, amelyhez a beavatkozástól való mentességet (noninterference) társítja.

Pettit szerint míg a liberális felfogásban az aktí beavatkozás minősül a szabadság korlátozásának, a republikanizmusban az önkényes beavatkozás lehetősége jelenti a szabadság hiányát, tehát az uralmat. Pettit szerint három tényezőnek kell teljesülnie ahhoz, hogy valóban uralomról beszéljünk. Egyrészt az uralmat gyakorló személynek bírnia kell a beavatkozás lehetőségével, másrészt a potenciális beavatkozásnak önkényes jellegünek kell lennie, harmadrészt pedig a lehetőségnek az uralmat elszenvedő személy életében központi szereppel bíró cselekedetekre vonatkozó döntési lehetőségeire kell irányulnia (i. m. 52-58.). A republikánus szabadságfogalom szemléltetésére a kortárs szerzők a klasszikus úr és szolga viszonyán túl a patriarchális házasságban élő férj és feleség, illetve a munkaadó és munkáltató kapcsolatát hozzák fel (a téma hazai irodalma közül Tóth Szilárd János tanulmánya [2019] szemlélteti a viszonyt találóan az iskolatársai által folyamatosan sakkban tartott diák példájával). A rabszolga esete mutat rá leginkább, hogy a szolga valójában abban az esetben sem szabad, ha jóindulatú ura mellett éppen a cselekedetei viszonylagos szabadságának örvend, hiszen a másik fél bármikor egyoldalúan megváltoztathatja a viselkedését, és korlátozhatja a szolga döntési lehetőségeit. Pettit szerint ebben áll a republikánus szabadságfogalom sikere a liberális megközelítéssel szemben: abból ugyanis, hogy az utóbbi az aktív beavatkozást teszi meg a szabadság mércéjének, az következik, hogy a szolga nagylelkü ura, a jóindulatú zsarnok nem tekinthető a szabadság akadályozójának; ez azonban ellentmond a rabszolgaságra vonatkozó intuícióinknak (Pettit, 2002: 22.). Ugyanez áll a férje jóakaratától függő feleség, a munkaadójának kiszolgáltatott alkalmazott és a kicsengetés után az iskolatársai miatt aggódó diák esetére. 
A Pettit által a liberális és republikánus szabadságfogalom között megállapított különbség két fontos implikációt von maga után. Egyrészről így a szabadság republikánus megközelítésében aktív beavatkozás nélkül is fennállhat a szabadság hiányának az állapota, másrészről viszont nem minden aktív beavatkozás jelenti a szabadság korlátozását. Az utóbbira példa a jog uralma: amennyiben a törvények igazságosak, nem korlátozzák az egyének szabadságát (i. m. 63-66.; Lovett - Pettit, 2009: 16.; Pettit, 2012b: 67.).

Pettit szerint ebben, a joghoz való eltérő viszonyában is megmutatkozik a republikánus és a liberális szemlélet különbsége, a liberális politikai filozófia hívei ugyanis a jogra, mint az egyéni szabadságot korlátozó szükséges rosszra tekintenek (Pettit, 2002: 84-85.). Pettit értelmezésében azonban az a törvény, amely a saját érdekében korlátozza, és ha szükséges, szankcionálja az egyént, az ezt nem az önkényes beavatkozás lehetősége révén teszi. Sőt, mivel az uralomtól való mentesség politikai ideál, ezért az államnak annak biztosítására, intézményesítésére kell törekednie, hiszen ez az egyetlen módja, hogy minél több állampolgár szabadsága legyen biztosított (i. m. 92.). Ez az alapvető republikánus eszme, a politikai szabadság értelmezése teszi Pettit szerint a republikánus politikaelméletet a domináns liberális politikaelmélet méltó kihívójává: az uralomtól való mentességként értett szabadság szerinte egy olyan felsőbbrendú politikai érték, amely a politikai berendezkedés elsődleges elve kell, hogy legyen. A társadalmi igazságosság rawlsi elveihez hasonlóan a republikánus szabadságideál is egy olyan neutrális elképzelés, amelynek a társadalmi intézményekben való megvalósítása lehetséges az egyéneknek a jóról való eltérő elképzelései ellenére (i. m. 96-97.; vö. Rawls, 2005: 29-35.).

A Pettit-féle irány egyik alapvető eleme tehát a szabadság két fogalmának elkülönítése. Ez azonban eltér a szabadság Isaiah Berlin (1990) által kidolgozott két fogalmától, és azok harmadik alternatívájaként jelenik meg. Berlin a szabadság negatív és pozitív fogalmát különböztette meg, ezek közül Pettit a beavatkozástól való mentesség liberális fogalmát a negatívval azonosítja. Az uralomtól való mentesség republikánus fogalmát azonban nem annak berlini értelemben vett ellentéteként, tehát pozitív szabadságként, hanem szintén a hiány fogalma révén definiálja (Pettit, 2002: 17-19. és 22.).

Pettit republikánus politikaelméletét számos kritika érte. A tanulmány szempontjából ezek közül azok érdekesek, amelyek arra vonatkoznak, hogy Pettit tévesen értelmezi a republikanizmus és a liberalizmus viszonyát, illetve helytelenül azonosítja a teljes liberális kánont a beavatkozástól való mentesség szabadságeszményével (Larmore, 2001 és 2012; vö. Pettit, 2002: 50.), ami azt sugallja, hogy a két áramlat között valójában nem is olyan mély a szakadék. Ezek a kritikák sokszor arra világítanak rá, hogy Pettit egyes elképzelései értelmezhetôk liberális keretek között, ha úgy tetszik azok is a liberális tradíció részei, sőt, kimondottan Rawls elképzeléseivel is azonosíthatók (Demeter, 2006; Larmore, 2001 és 2012b; Saenz, 2008; Simpson, 2017; Tóth, 2019). 
Pettit politikaelméletének fentebb vázolt elemeiből kitûnik, hogy annak sem a migráció, sem egyéb, a főáramú politikatudományban általában „külsőnek” vagy „nemzetközinek” tekintett téma nem képezi tárgyát. Ezt a tényt, illetve az említett kritikákat tekintetbe véve két kérdés merül fel a migráció politikaelméletére vonatkozóan. Az egyik az, hogy mennyiben képes a migráció liberális politikaelméletének hibáit meghaladni a republikánus alternatíva annak fényében, hogy a két irány (és elsősorban Rawls és Pettit elképzelései) között nem is olyan nagy a szakadék, mint azt Pettit látni véli. A másik kérdés pedig az, hogy a két politikaelmélet hasonlóságai ellenére lehetséges-e, hogy a migráció témájának tekintetében a republikánus politikaelmélet lényegesen nagyobb potenciállal bír, így esetleg hozzá tud járulni a migrációról való szisztematikus politikai gondolkodás megalapozásához. A tanulmány harmadik fejezetében amellett fogok érvelni, hogy Pettit a rawlsi ontológiára alapozza a migrációra vonatkozó észrevételeit, emiatt óhatatlanul ugyanazokkal a kihívásokkal szembesül, mint liberális kortársai.

Mielőtt azonban erre rátérnék, felvázolok négy olyan sajátosságot, amelyek véleményem szerint alkalmassá teszik a republikánus politikaelméletet, hogy a migrációhoz kapcsolódó témák normatív értelmezéseit gyarapítsa, a migráció politikaelméletének egy átfogó megközelítéséhez lehetséges témákat és problémákat vessen fel, valamint ezekhez értelmezéseket nyújtson. A négy sajátosságot a szabadság republikánus fogalma, a republikanizmus igazságtalanságra irányuló fókusza, a radikalizmusa, illetve az általa kínált konszenzus lehetősége jelenti.

Az első ok a republikanizmus pettiti megközelítésének alapvető eszméjéhez, az uralommentességként értett szabadság fogalmához kapcsolódik. Mivel ez a fogalom egyrészról tágabb, más tekintetben viszont szúkebb a liberális szabadságfelfogáshoz képest, ezért két dimenzióban járulhat hozzá a migráció és mobilitás témáinak vizsgálatához. A republikánus eszme az interperszonális viszonyok sokkal tágabb rétegét predesztinálja a szabadsághiány kategóriájába (Pettit, 2002: 63-64.), így számos olyan társadalmi kapcsolatot is elnyomónak, igazságtalannak tekint, amelyet a liberális szabadságideál nem. Ennek köszönhetően egy republikánus perspektívát alkalmazva magától értetődően merül fel, hogy nem csupán a társadalmon belüli viszonyok, de az államhatárokon átívelő jelenségek és szervezetek esetében megvalósul-e az érintett egyének szabadsága. Így a republikánus politikaelmélet múvelői számára kézenfekvő a bevándorlás (a fogadó állam és a bevándorlók oldaláról egyaránt), valamint az emigráció, a menekültek és a nemzetközi szervezetek problematikájának szempontjából is vizsgálni a szabadság kérdését.

A szabadság fogalmának másik dimenzióját tekintve a republikanizmus egyúttal sokkal szúkebb definíciót kínál a fogalom liberális értelmezésénél (i. m. 65-66.). Mivel Pettit szerint nem minden aktív beavatkozás minősül uralomnak, köztük elsősorban a jog által (igazságos törvények és szankciók for- 
májában) megvalósuló beavatkozás sem, ezért a szabadságfogalom a migráció tekintetében egy fontos implikációt von maga után. A menekültekre vonatkozó nemzetközi jogi előírásokat leszámítva egy személy csak akkor minősül egy állam jogrendszere tárgyának, ha állampolgárként, lakosként, átmeneti lakosként számon van tartva vagy egyéb okokból, például turistaként vagy éppen valamilyen „illegális" módon belép az állam területe és joghatósága alá. Ezért az igazságos törvények - nem uralomnak tekintett - korlátozásai az egyének egy meghatározott körére terjednek ki. Ennek a körnek a meghatározásában azonban a modern államnak egészen széleskörü diszkrecionális joga van: sok állam a bevándorlás korlátozása vagy éppen az illegálisnak tekintett személyek elkülönítése, deportálása révén számos egyént egyszerúen kirekeszt az igazságos törvények védelme alól. Ezek a személyek gyakran a munkáltatójuk, a főbérlőjük, vagy épp emberkereskedők fennhatósága alatt élnek (Fine, 2014). Sôt, a 2001. szeptember 11-i amerikai terrortámadások nyomán bevett szokássá vált, hogy a közösség tagjaira veszélyt jelentő személyeket az állam megfosszon jogaitól, vagy egyszerűen dehumanizáljon, és a jog fennhatósága alá kevésbé eső intézményekben zárjon el (Ahmad, 2009; Bosniak, 2010). Bár a terrorizmus vádjával illetett egyének esete szélsőségesnek tûnik, a példából mégis jól látszik, hogy jog egy meghatározott politikai közösségre vonatkozik, és annak peremén, a (gyakran amúgy is kiszolgáltatottabb helyzetben lévő) bevándorlók, a „vendégmunkások”, de előfordulhat, hogy külföldi diákok vagy akár turisták esetében a hatóságoknak sokkal több tere nyílik az egyéni mérlegelésre. A szabadság republikánus fogalmának ez a dimenziója tehát lehetôvé teszi annak a területnek a beazonosítását, amely esetén a jog beavatkozása tökéletlen, így nagyobb eséllyel hoz létre uralmi viszonyt.

A második ok, amely vonzóvá teszi a republikánus politikaelméletet, az a jellegzetessége, hogy a domináns liberalizmus igazságosság fogalma helyett az igazságtalanságra koncentrál (Bohman, 2012). Amíg Rawls a társadalmi igazságosság eszméjét (a méltányosságként értett igazságosság két elvét) határozta meg, addig Pettit az igazságtalanság, azaz az uralom definícióján keresztül jut el a republikanizmus eszméjének, a szabadságnak a meghatározásához (vö. Pettit, 2002; Rawls, 1997 és 2005). Emiatt a republikanizmus egyszerre tekinthető a nem ideális elméletek és a kritikai elmélet egy típusának is, amely lehetôséget nyújt arra, hogy a normatív megközelítések a társadalmi világ olyan igazságtalanságait is figyelembe vegyék, amelyeket korábban nem vizsgáltak a politikai filozófusok (Bohman, 2012). Ez a jellegzetesség a migráció témájára vetítve ahhoz vezet, hogy a republikanizmus a legsebezhetőbb személyekre fókuszáljon mind a politikai közösség meglévő, mind a lehetséges tagjai így a bevándorlók és menekültek - körében is. Ráadásul az irányzat arra is alkalmas lehet, hogy a szisztematikus igazságtalanságokat vizsgálja (Thompson, 2013), ezáltal a migráció politikaelméletét a határellenőrzésért felelős hatóságok által és a menekülttáborokban történő igazságtalanságokra való rámuta- 
tással gazdagítsa (ezt teszi például Honohan, 2014; Hoye, 2018; Sager, 2017). Az igazságtalanságra fókuszálás teszi lehetővé, hogy a migráció republikánus politikaelmélete a társadalmi státuszra helyezze a hangsúlyt. Pettit értelmezésében a szabadság egy olyan társadalmi státusz, amelyben az egyén viszonylag biztosított mások önkényes beavatkozásával szemben, a közösség többi tagjával egyenrangúnak tekinti és biztonságban érzi magát (Pettit, 2002: vii., 31.). Ezek a személyek „egymás szemébe nézhetnek”, mások előtt „nem kell meghajolniuk" (i. m. 87.). Ezt az állapotot elsősorban az állampolgárság biztosíthatja, így akik valamiért nem részesülnek állampolgári jogokban, azok alárendelt társadalmi helyzetbe kerülnek (Bosniak, 2010; Benton, 2014; Fine, 2014; Walzer 1984: 2. fejezet). Ennek megfelelően a migráció republikánus megközelítéseiben szubsztantív igényként fogalmazódhat meg az igazságtalanságnak, uralomnak legkitettebb személyek az állampolgárságéhoz hasonló jogainak elismerése.

A harmadik ok, amiért a kortárs republikánus politikaelmélet megnyerőbb lehet a rawlsi liberalizmusnál, az a radikalizmusa a meglévő társadalmi intézményekkel szemben. A liberális politikaelmélettel szemben a republikanizmus sokkal szkeptikusabb a társadalmi intézményekhez való viszonyában, miközben egyúttal „kevésbé szkeptikus azoknak az állam révén történő rendbetételének lehetőségével szemben" (Pettit, 2002: 78.). Ennek alátámasztására Pettit bemutatja, hogy a republikánus szabadság egy nyitott eszme, amely vonzó lehet olyan többé-kevésbé radikális mozgalmak számára is, amelyek a környezetvédelmet, feminizmust, szocializmust, vagy akár a multikulturalizmust túzik zászlajukra (i. m. 130-147.). Bár ezeknek a mozgalmaknak mind elképzelhető transznacionális, globális formája, itt ezeket Pettit a társadalmon belüli mozgalmakként írja le. Ettôl függetlenül az a meglátása, hogy az egyes társadalmi kérdésekben lévő kisebbségi vélemény, a tradicionálisan női szerepekkel járó függés, a munkavállalók gazdasági függése és a kisebbségi kultúrákhoz való tartozás mind az uralomtól való függés egy-egy formája lehet, arra enged következtetni, hogy a republikanizmus iránytû lehet olyan kérdésekben is, mint amilyen a migráció. Mivel a migráció egyes aspektusaiban éppen halmozottan jelennek meg a kiszolgáltatottság Pettit által felsorolt formái, egy Pettitre alapozó republikánus politikaelméleti gondolkodó érvelhet amellett, hogy az irányzatnak ez a radikalizmusa lehetővé teszi, hogy a migráns személyek szempontjából is megfogalmazódjon a szabadságukat korlátozó uralmi viszonyok kritikája.

A negyedik ok, amiért az irányzat kihívója lehet a migráció domináns politikaelméletének, az a jellegzetesség, hogy a republikanizmus Pettit megfogalmazásában alkalmas a társadalom tagjai közötti magasabb rendú konszenzus kialakítására. Ennek az okát abban látja Pettit, hogy az állami cselekvést irányító érdekeket és elképzeléseket a társadalom bármely szegletéből kifogásolhatóvá kell tenni, az eljárásokat pedig konszenzusnak kell öveznie (i. m. 
56.). Ez a jellegzetesség lehetőséget ad, hogy az uralmi viszonyok már említett klasszikus tipológiáján túl az uralom egyéb, a migráció szempontjából releváns formáit is azonosíthassuk. Ilyen például az állampolgár és a nem állampolgár viszonya (Benton, 2014; Fine, 2014; Hovdal-Moan, 2014; Hoye, 2018), illetve hasonló alapon fogalmazható meg republikánus értelmezésben a kapcsolat a határellenőrzések, az állami bürokrácia, egyéb hatóságok illetve a bevándorlók és menekültek között (Honohan, 2014; Sager, 2017). Az utóbbi kapcsán mindenképp felmerül a migráció domináns politikaelmélete néhány elképzelésének megkérdőjelezése. A módszertani nacionalizmus kritikusai felhívták a figyelmet arra, hogy a határokellenőrzések rendkívül mobilisek, nem feltétlenül az államhatáron és nem minden esetben az állam területére való belépéskor történnek (Sager, 2016 és 2018; Shachar 2009). Mivel a határellenőrzés gyakran rendkívül komplex folyamat, megnő a hivatalnokok egyéni mérlegelési lehetőségének területe, ezzel párhuzamosan pedig rendkívüli mértékben nő meg az olyan tényezők szerepe az elbírálásban, mint a rasszizmus és a szexizmus (Fine, 2016), hiszen a bürokratikus „részrehajlás ott kezdődik, ahol a jog véget ér" (Sager, 2017: 44.). A migráció politikaelméletének republikánus megközelítése így annak megvilágítására is alkalmas lehet, hogy nem csupán a bevándorlók szembesülnek a hatósági „vegzálásokkal”, hanem gyakran leszármazottjaik, második és harmadik generációs bevándorlók is azok árnyékában, bizonytalanságban élnek (Laborde, 2008: 184-201.; Sager, 2018: 5. fejezet). A republikánus nézőpont arra is lehetőséget ad, hogy megkülönböztessünk valódi és potenciális bevándorlókat. Az utóbbiak esetén felmerülhet, hogy sokakat épp az említett bürokratikus uralomgyakorlás kellemetlenségei tántorítanak el attól, hogy egy másik állam területére és joghatósága alá kérjenek bebocsátást. Emellett ez a szemlélet felvetheti az uralmi viszonyok kérdéseit a nemzetközi szereplők (például NGO-k és multinacionális vállalatok) vonatkozásában (Bohman, 2012).

A Pettit-féle kortárs republikánus politikaelmélet tehát széleskörü, a migráció politikaelméleti megközelítéséhez alkalmazható eszköztárat kínálhat, amelynek néhány elemére (bár elsősorban a szabadság republikánus fogalmára) építve több szerző már megkísérelte a migráció politikaelméletét gazdagítani. Ugyanakkor nem mehetünk el szó nélkül a tény mellett, hogy néhány tanulmányban maga Pettit is megosztotta néhány gondolatát, amelyek ha nem is a migrációról, de a nemzetközi viszonyok kérdéseiről szólnak. Mivel a politikaelmélet múvelői jellemzően a nemzetközi viszonyok kapcsán foglalkoznak a migráció témájával, ezért célszerú megvizsgálni, hogy Pettitnek a témában született elképzelései alátámasztják-e a republikanizmusnak ebben a fejezetben vázolt potenciálját. A következő fejezetben arra az érdekességre mutatok rá, hogy Pettit a migrációra vonatkozó elképzeléseiben nem él a republikánus megközelítés adta lehetőségekkel, mert ezekben reprodukálja a mainstream politikaelmélet előfeltevéseit. 


\section{A MIGRÁCIÓ TÉMÁJA PETTIT MEGKÖZELÍTÉSÉBEN}

Pettit néhány, a Republicanism után született mûvéből következtethetünk a nemzetközi viszonyokkal, így a migrációval kapcsolatos elképzeléseire is. Amellett kívánok érvelni, hogy ezekben Pettit nem képes szubsztantív jelleggel hozzájárulni a migráció politikaelméleti vizsgálataihoz, legalábbis nem olyan mértékben, mint azt a republikanizmusban rejlő, az előző fejezetben tárgyalt lehetőségek prognosztizálnák. Ennek okát abban látom, hogy Pettit nem csupán szimpatizál Rawlsnak a témával kapcsolatos néhány meglátásával, hanem expliciten azok mintájára dolgozza ki saját nemzetközi viszonyokra vonatkozó elméletét. Ebből fakad, hogy figyelmen kívül hagyja a nemzetközi szférában előforduló uralom számos formáját. Pettit szintén a migráció domináns politikaelméletének mintájára szigorúan elkülöníti a „belső" és a „nemzetközi” szférát egymástól, reflexió nélkül hagyja a világ múködésének számos, a republikanizmus szempontjából fontos dimenzióját, köztük az internacionális migráció jelenségét.

Pettit A Republican Law of Peoples címet viselő, 2010-es tanulmányában igyekszik összefoglalni a republikánus eszme kívánalmait a nemzetközi rendre nézve - ahogyan az a tanulmány címéből is kiderül, bevallottan Rawls A Law of Peoples címú múvének mintájára (2008 [1993]); majd pedig a 2014-es könyvének utolsó fejezetében foglalkozik a kérdéssel (Pettit, 2010 és 2014). Pettit a republikanizmus szabadságfogalmára építve azt mutatja be, milyen berendezkedést kívánna meg az uralomtól való mentesség eszméje a nemzetközi viszonyok terén, illetve igyekszik rávilágítani az általa kínált alternatíva erősségeire a liberális (és elsősorban rawlsi) megközelítéssel szemben. A „republikánus népek joga" egyébként nem előzmény nélküli: Pettit már máshol is foglalkozott Rawlsnak a néppel kapcsolatos ontológiájával, és célzott annak saját elméletével való hasonlatosságaira (Pettit, 2005 és 2006).

Pettit nemzetközi viszonyokról szóló elméletének alapvető kérdése, mit kívánna meg a nemzetközi rend ideálja. Erre a kérdésre - akárcsak Rawls (2008) - a nemzetközi viszonyok meglévő egységeit, az államokat veszi alapul. ${ }^{3} \mathrm{~A}$ tanulmány alapja az államok megkülönböztetése két dimenzió alapján: egyrészt elkülönít effektív és nem effektív államokat (aszerint, hogy azok képesek-e az állampolgáraik számára biztosítani az alapvető szolgáltatásokat), illetve reprezentatív és nem reprezentatív államokat (az alapján, hogy a nép nevében cselekednek-e) (Pettit, 2010: 71-72.). Akárcsak Rawls (2008: 33-39.), Pettit is azokra az államokra vonatkoztatja az ideált, amelyek képesek a nép akaratával összhangban cselekedni, tehát Pettit megfogalmazásában effektívek és reprezentatívak. Bár Pettit leszögezi, hogy nem az érvelés, hanem csupán a struktúra szempontjából épít a rawlsi modellre (Pettit, 2010: 72.), feltehetőleg azért, hogy a két elképzelés összehasonlíthatóvá váljon, ezzel valójában már a gondolatmenet elejétól fogva kizár számos olyan kérdést - például a Rawls által is 
csak felületesen kezelt migrációt -, ami a nemzetközi viszonyok republikánus megközelítésében adott lenne.

A nemzetközi rend megfelelő ideálja a (reprezentatív) államok között megvalósuló uralomtól való mentesség Pettit szerint (i. m. 73.), aki nemzetközi szinten az uralomnak három formáját különbözteti meg: a két állam közöttit, a privát nemzetközi szereplők részéről érkezőt (ide tartoznak a multinacionális vállalatok, az egyházak, a terrorista szervezetek és néhány nagy hatalommal bíró személy), valamint a nemzetközi szervezetek felől érkezőt (mint amilyen az ENSZ, a Világbank, az IMF, az EU vagy a NATO). A tanulmányban Pettit részletesen bemutatja, hogy ezek milyen eszközök révén élhetnek aktív beavatkozással és rávilágít, hogy - a republikánus ideálnak megfelelően - ezek abban az esetben is korlátozzák az állam és azáltal polgárai szabadságát, ha csupán a beavatkozással való fenyegetéssel élnek vagy amikor a gyengébb államoknak a tőlük való függésére apellálnak (i. m. 77-79.). Pettit szerint az uralommal szembeni megoldás csakis a nemzetközi intézményekben való deliberáció, emellett pedig a gyengébb államoknak az erősebb államokkal és a nagy befolyással bíró multinacionális vállalatokkal szembeni összefogása lehet (i. m. 79-86.). A nem reprezentatív államokkal szembeni fellépést pedig a társadalom kormányzatra való nyomásgyakorlása révén, az intervencióra való felszólítással képzeli el (i. m. 90.). Pettit szerint ez az elképzelés azért lehet kihívója a nemzetközi viszonyok rawlsi elméletének, mert a megvalósítására sokkal nagyobb az esély a világ jelenlegi körülményei között, és mert a szabadság republikánus fogalma révén felismer olyan igazságtalanságokat, amilyeneket a csupán az aktív beavatkozást rossznak tekintő liberális szabadságfelfogás nem (i. m. 86.).

Ahogy említettem, az uralommentességnek a szabadság liberális felfogásával való összehasonlítása több szempontból kifogásolható (lásd például Larmore, 2001 és 2004), azonban azzal, hogy a szereplők közti viszonyok egy szélesebb körét teszi kritika tárgyává, Pettit lehetőséget nyitna a migrációval kapcsolatos igazságtalanságok vizsgálata előtt. A következőkben bemutatom, ennek ellenére miért nem nyitja meg a nemzetközi elméletét Pettit a migráció témája előtt.

A hiányosság oka a rawlsi séma másolása. Ez azonban önmagában nem jelentene problémát: mivel Rawls és Pettit a klasszikus, "belső" elméleteikben nem foglalkoznak olyan jelenségekkel, amelyek átnyúlhatnak az állam határain és joghatóságán, ezért kézenfekvő igény lehet számonkérni az ott mellőzött témákat ezeknek a szerzőknek a nemzetközi keretekre vonatkozó elképzeléseiken. Pettit a témáról szóló könyvfejezetében kiköti, hogy az általa megfogalmazott ideál „nem vonatkozik az állam belső szerveződésére”, hanem "teljes mértékben a nemzetközi szférához tartozik" (Pettit, 2014: 6. fejezet). A két „népek joga” egy-egy elképzelést takar a nemzetközi rend ideáljáról, nem pedig a nemzetközi rend átfogó elméletét, és kiváltképp nem a migráció politikaelméletét jelenti. Csakhogy a republikanizmus pettiti ideálja, azaz az ura- 
lommentesség ennél többet is takar. Pettit azzal indokolja az elképzelését, amely szerint ennek az elvnek kell vezérelnie a nemzetközi viszonyokat, hogy a republikanizmusnak megfelelően az egyéneket az (uralmat nem gyakorló) állam védelmezi a mások általi uralomtól, viszont ha maga az állam más (nemzetközi) szereplők uralma alatt áll, akkor a polgárai sem szabadok. Tehát az állampolgár politikai szabadságát csakis az uralmat nem gyakorló és nem elszenvedő állam biztosíthatja (i. m. 77.). Ez alapján Pettit konstrukciója nem a társadalomtól függetlenül kezelt nemzetközi rend elmélete, hanem a politikai közösség republikánus elméletének kiterjesztése egy globális keretbe: a pettiti elképzelés tehát a politikai szabadságnak nem a rawlsi sémára alapozott nemzetközi elmélete, hanem a politikai szabadság globális elmélete.

Ezt tekintetbe véve láthatóvá válik, miért problematikus, hogy Pettit nem foglalkozik az uralomnak azokkal a dimenzióival, amelyeket egy ilyen, globális szemlélet megkívánna. Elsősorban ilyen a reprezentatív állam részéről azokat érő uralom, akik nem tagjai a népnek, akár az állam területén, akár azon kívül tartózkodnak (Thomas, 2015: 579-580.). Erre tökéletes példa a már említett hatósági ellenőrzések és határellenőrzés esete, amelyekben a jog kevésbé védelmezi az állampolgári státusszal nem rendelkezőket a hivatalnokok és szervek egyéni mérlegelési szempontjaival szemben. Azzal tehát, hogy Pettit egyszerúen a rawlsi keretrendszerre építi a nemzetközi viszonyokra vonatkozó elméletét, túl gyorsan feledkezik meg arról, hogy épp a republikánus szabadságeszmény miatt nem hagyhat szó nélkül olyan tényezőket, amelyek mellett Rawls elsiklott.

Rawlsnál és Pettitnél is - bár csak néhány megjegyzés erejéig - problémaként jelenik meg a migráció: Rawlsnál szembetûnő, hogy az „emigráció” egyenlőtlenségek és elnyomás, tehát igazságtalanságok következménye, a migráció egyéb formái pedig fel sem merülnek igazán nála (Rawls, 2008: 18-19.). Pettit szintén szúkszavú a témát illetően, csak a bevándorlást említi problémaként: a gyengébb államok polgárai elvándorolhatnak más államokba a jobb lehetőségek érdekében (Pettit, 2010: 86.), illetve Rawls megoldását követve, a szöveg végén a nem reprezentatív államokkal szembeni fellépés szükségessége mellett az azok által elindított „illegális migrációs hullámokat” említi meg (i. m. 70.).

Leszámítva az uralmi viszonyok néhány új dimenzióját, valamint az uralomgyakorlás módjainak egy rendkívül bő listáját, a migráció politikaelméletének szemszögéből nézve Pettit mégsem él azzal a lehetőséggel, amelyet a kortárs republikánus politikaelméletet megalapozó Republicanism címü könyvében foglalt elképzelések kínálnak a téma megközelítésére. Ahogy Pettit egy helyen fogalmaz éppen Rawlsszal kapcsolatban: „egy szerző munkája megközelítései közül az egyik legérdekesebb megtalálni azt az előfeltételezést, amely motiválja vagy behatárolja az érvelés nagy részét, miközben sosincs expliciten kimondva" (Pettit, 2005: 157.). Ha a migrációval kapcsolatos elképzeléseit vagy éppen azok hiányát vesszük szemügyre, akkor egyértelmúvé válik, hogy Pettit 
elképzelései nem állnak olyan távol a liberális megközelítésektől, mint az elsőre tûnhet: ugyanazok a korlátok konstruálják Pettit észrevételeit, amelyek a migráció liberális politikaelméletét is visszavetik. Ezzel szemben a republikanizmus valójában egy új fogalmi keretrendszert kínál a migráció liberális politikaelmélete korlátainak meghaladására (Chung, 2012; Laborde, 2010). A republikánus politikaelméletben rejlő lehetőség többek fantáziáját megmozgatta: izgalmas tanulmányok sora született a republikanizmus szabadságfogalmára alapozva olyan témákban, amelyekre a migráció egy alapos, szisztematikus politikaelméletének biztosan reflektálnia kell.

\section{ÖSSZEFOGLALÓ}

A tanulmány arra a kérdésre keresi a választ, hogy kihívója lehet-e a kortárs republikánus politikaelmélet a domináns, liberális politikaelméletnek a migráció témájának tárgyalásakor. Bemutattam, hogy a migráció kortárs politikaelmélete korlátozottságai miatt nem képes a jelenséget megfelelőképp leírni, és annak normatív implikációira választ találni. Pedig, ahogy azt bemutattam, a kortárs republikanizmus, elsősorban Philip Pettit politikaelmélete, széleskörű eszköztárat jelent a migráció politikaelméletének megközelítéseihez. Arra mutattam rá, hogy négy fő tényező szisztematikus tárgyalása tehetné a Pettitféle republikanizmust a domináns, liberális politikaelmélet alternatívájává: ezek a szabadság republikánus fogalma, a republikanizmusnak az igazságtalanságra irányuló fókusza, a radikalizmusa, illetve a republikanizmus által kínált magasabb rendű konszenzus lehetősége.

Bár a migráció republikánus politikaelméletéről nem született még átfogó mú, több szerző kifejezetten Pettit elképzeléseire építve foglalkozott ezekkel a kérdésekkel, amelyeket republikánus szemmel problematikusnak vélnek. Ehhez képest Pettitnek a migrációhoz kapcsolódó elképzelései ugyanazokat a problémákat adják vissza, mint a liberális politikaelmélet. Nem véletlenül, saját elméletének potenciálját hanyagolva Pettit, a nemzetközi kérdésekben (amelyek között helyet kaphatnának a migráció egyes aspektusai és implikációi) inkább bevallottan Rawls elképzeléseire épít. Pedig, ahogyan érvelni igyekeztem, a republikánus szemlélet igencsak gazdagíthatná a migráció egy alapos, koherens és konzisztens politikaelméletét.

Nem gondolom, hogy választanunk kellene, hogy a migráció politikaelmélete liberális vagy republikánus legyen. Mivel a két eszme kortárs megvalósulása láthatóan nincs olyan távol egymástól, mint első látásra tûnhet, ezért sikerrel kecsegtethet a republikánus eszköztár beemelése a migráció meglévő politikaelméletébe. A liberalizmus és republikanizmus egymás javára, semmint egymás rovására bővíthetik a migrációról való ismereteinket. 


\section{JEGYZETEK}

${ }^{1}$ Bár Michael Walzer ennél pár évvel korábbi, 1984-es Spheres of Justice címú könyvének a politikai közösségben való tagságról szóló fejezete több érdekes meglátással szolgál a migráció tekintetében is.

${ }^{2}$ A kozmopolitizmusnak számos formáját különbözteti meg a szakirodalom, köztük a leggyakoribb a kozmopolitizmus morális értelemben való használata. Mivel azonban ez nem jelent többet annál az elképzelésnél, hogy minden egyén egyenlő morális értékkel bír, ezért az elképzelés mellett való elköteleződés nem tesz bennünket egyúttal a nyílt határok elkötelezettjeivé is (lásd Bernstein, 2011; Sager, 2018: 9.).

${ }^{3}$ Bár Rawls esetében a népekről van szó (Rawls, 2008: 33-39.), ennek az összehasonlítás szempontjából nincs túlzott jelentősége, csupán annyi, hogy a nép az őt reprezentáló kormányzaton keresztül cselekszik (Pettit, 2005; 2006).

\section{IRODALOM}

Abizadeh, Arash (2008): Democratic Theory and Border Coercion: No Right to Unilaterally Control Your Own Borders. Political Theory, 36 (1): 37-65. https://doi.org/10.1177/0090591707310090.

Abizadeh, Arash (2010): Democratic Legitimacy and State Coercion: A Reply to David Miller. Political Theory, 38 (1): 121-130. https://doi.org/10.1177/0090591709348192.

Abizadeh, Arash (2016): The Special-Obligations Challenge to More Open Borders. In: S. Fine-L. Ypi (szerk.): Migration in Political Theory, 105-124. https://doi.org/10.1093/acprof:oso/9780199676606. 003.0006 .

Ahmad, Muneer (2009): Resisting Guantanamo: Rights at the Brink of Dehumanization. American University, WCL Research Paper, No. 8-65.

Balibar, Étienne (2002): Politics and the Other Scene. London, Verso.

Beck, Ulrich (2000): What is Globalization? Cambridge, Malden, Polity Press.

Beck, Ulrich (2002): The Terrorist Threat: World Risk Society Revisited. Theory, Culture \& Society, 19 (4): 39-55. https://doi.org/10.1177/0263276402019004003.

Benton, Meghan (2014): The Problem of Denizenship: A Non-Domination Framework. Critical Review of International Social and Political Philosophy, 17 (1): 49-69. https://doi.org/10.1080/13698230. 2013.851479.

Berlin, Isaiah (1990): Négy esszé a szabadságról. Budapest, Európa Könyvkiadó.

Bernstein, Alyssa (2011): Political Cosmopolitanism. In: D. K. Chatterjee (szerk.): Encyclopedia of Global Justice, 857-863. https://doi.org/10.1007/978-1-4020-9160-5_351.

Blake, Michael (2013): Immigration, Jurisdiction, and Exclusion: Immigration, Jurisdiction, and Exclusion. Philosophy \& Public Affairs, 41 (2): 103-130. https://doi.org/10.1111/papa.12012.

Blake, Michael (2014): The Right to Exclude. Critical Review of International Social and Political Philosophy, 17 (5): 521-537. https://doi.org/10.1080/13698230.2014.919056.

Bohman, James (2007): Democracy Across Borders: From Dêmos to Dêmoi. Cambridge, MIT Press.

Bohman, James (2012): Critical Theory, Republicanism, and the Priority of Injustice: Transnational Republicanism as a Nonideal Theory: Critical Theory, Republicanism, and the Priority of Injustice. Journal of Social Philosophy, 43 (2): 97-112. https://doi.org/10.1111/j.1467-9833.2012.01554.x. 
Bosniak, Linda (2010): Persons and Citizens in Constitutional Thought. International Journal of Constitutional Law, 8 (1): 9-29. https://doi.org/10.1093/icon/mop031.

Carens, Joseph (1987): Aliens and Citizens: The Case for Open Borders. The Review of Politics, 49 (2): 251-273. https://doi.org/10.1017/s0034670500033817.

Carens, Joseph (2013): The Ethics of Immigration. Oxford, New York, Melbourne, Madrid, Toronto, Oxford Univerisity Press. https://doi.org/10.3402/egp.v7.24942.

Chung, Ryoa (2012): The Cosmopolitan Scope of Republican Citizenship. In: Weinstock - Nadeau (szerk.): Republicanism: History, Theory, and Practice. 117-133. https://doi.org/10.1080/1369823 0510001702713.

Cole, Phillip (2000): Philosophies of Exclusion: Liberal Political Theory and Immigration. Edinburgh, Edinburgh University Press.

Demeter M. Attila (2006): Mi a republikanizmus? Székelyföld, Nr. 1, 355-365, ISSN: 1453-3871.

Fine, Sarah. (2014): Non-Domination and the Ethics of Migration. Critical Review of International Social and Political Philosophy, 17 (1): 10-30. https://doi.org/10.1080/13698230.2013.851481.

Fine, Sarah. (2016): Immigration and Discrimination. In: S. Fine-L. Ypi (szerk.): Migration in Political Theory. 125-150. https://doi.org/10.1093/acprof:oso/9780199676606.003.0007.

Fine, Sarah-Ypi, Lea (szerk.) (2016): Migration in Political Theory: The Ethics of Movement and Membership. Oxford, United Kingdom: Oxford University Press. https://doi.org/10.1093/acprof:oso/978019 9676606.001.0001.

Honohan, Iseult (2002): Civic republicanism. London, Routledge. https://doi.org/10.4324/9780203460894.

Honohan, Iseult (2014): Domination and Migration: an Alternative Approach to the Legitimacy of Migration Controls. Critical Review of International Social and Political Philosophy, 17 (1): 31-48. https:// doi.org/10.1080/13698230.2013.851482.

Honohan, Iseult-Jennings, Jeremy (2015): Republicanism in Theory and Practice. London, Routledge.

Hovdal-Moan, Marit (2014): Unequal Residence Statuses and the Ideal of Non-domination. Critical Review of International Social and Political Philosophy, 17 (1): 70-89. https://doi.org/10.1080/136 98230.2013.851483.

Hoye, Matthew (2018): Migration, Membership, and Republican Liberty. Critical Review of International Social and Political Philosophy, 1-27. https://doi.org/10.1080/13698230.2018.1532228.

Laborde, Cécile (2008): Critical Republicanism: The Hijab Controversy and Political Philosophy. OxfordNew York, Oxford University Press.

Laborde, Cécile (2010): Republicanism and Global Justice: A Sketch. European Journal of Political Theory, 9 (1): 48-69. https://doi.org/10.1177/1474885109349404.

Laborde, Cécile-Maynor, John (szerk.) (2008): Republicanism and Political Theory. Malden, Blackwell.

Larmore, Charles (2001): A Critique of Philip Pettit's Republicanism. Philosophical Issues, 11. Social, Political, and Legal Philosophy, 229-243.

Larmore, Charles (2012): Liberal and Republican Conceptions of Freedom. In: Weinstock - Nadeau (szerk.): Republicanism: History, Theory, and Practice. 83-103.

Lovett, Frank (2010): A General Theory of Domination and Justice. New York, Oxford University Press. https://doi.org/10.1093/acprof:oso/9780199579419.001.0001.

Lovett, Frank. (2016): Civic Republicanism and Social Justice. Political Theory, 44 (5): 687-696. https:// doi.org/10.1177/0090591716663275. 
Lovett, Frank-Pettit, Philip (2009): Neorepublicanism: A Normative and Institutional Research Program. Annual Review of Political Science, 12 (1): 11-29. https://doi.org/10.1146/annurev.polisci.12.040907.120952.

Martí, José Luis-Pettit, Philip (2010): A Political Philosophy in Public Life: Civic Republicanism in Zapatero's Spain. Princeton, Princeton University Press. https://doi.org/10.1002/j.1538-165X.2011.tb02181.x.

Miller, David (2005): Immigration: The Case for Limits. In: Andrew Cohen-Christopher Heath Wellman (szerk.): Contemporary Debates in Applied Ethics, 193-206. Malden, Blackwell.

Miller, David (2010): Why Immigration Controls Are Not Coercive: A Reply to Arash Abizadeh. Political Theory, 38 (1): 111-120. https://doi.org/10.1177/0090591709348194.

Miller, David (2016a): Strangers in Our Midst: The Political Philosophy of Immigration. Cambridge, Harvard University Press. https://doi.org/10.1093/migration/mnw033.

Miller, David (2016b): Is There a Human Right to Immigrate? In: S. Fine-L. Ypi (szerk.): Migration in Political Theory, 11-31. https://doi.org/10.1093/acprof:oso/9780199676606.003.0002.

Nail, Thomas (2015): The Figure of the Migrant. Stanford, Stanford University Press.

Oberman, Kieran (2016): Immigration as a Human Right. In: S. Fine-L. Ypi (szerk.): Migration in Political Theory. 32-56. https://doi.org/10.1093/acprof:oso/9780199676606.003.0003.

Pettit, Philip (1996): Freedom as Antipower. Ethics, 106 (3): 576-604.

Pettit, Philip (2002): Republicanism: A Theory of Freedom and Government. Reprinted Version. OxfordNew York, Clarendon Press-Oxford University Press.

Pettit, Philip (2005): Rawls's Political Ontology. Politics, Philosophy \& Economics 4 (2): 157-174. https:// doi.org/10.1177/1470594X05052536.

Pettit, Philip (2006): Rawls's Peoples. In: Rex Martin-David Reidy (szerk): Envisioning a New International Order: Essays on Rawls's Law of Peoples. 38-55. Blackwell, Oxford, 2005.

Pettit, Philip (2010): A Republican Law of Peoples. European Journal of Political Theory, 9 (1): 70-94. https://doi.org/10.1177/1474885109349406.

Pettit, Philip (2012a): On the People's Terms: A Republican Theory and Model of Democracy. https://doi. org/10.1017/CBO9781139017428.

Pettit, Philip (2012b): Discourse Theory and Republican Freedom. In: Weinstock - Nadeau (szerk.): Republicanism: History, Theory, and Practice. 62-82.

Pettit, Philip (2014): Just Freedom: A Moral Compass for a Complex World. New York, Norton.

Pevnick, Ryan (2014): Immigration and the Constraints of Justice Between Open Borders and Absolute Sovereignty. Cambridge, Cambridge University Press.

Rawls, John (1997): Az igazságosság elmélete. Budapest, Osiris.

Rawls, John (2005): Political Liberalism (bővített kiadás). New York, Columbia University Press.

Rawls, John (2008): A népek joga: Visszatérés a közös gondolkodás eszméjéhez. Fordította: Krokovay Zsolt. Budapest, L'Harmattan.

Saenz, Carla (2008): Republicanism: An Unattractive Version of Liberalism. Ethic@ An International Journal for Moral Philosophy, 7 (2) 267-285. https://doi.org/10.5007/1677-2954.2008v7n2p267.

Sager, Alex (2016): Methodological Nationalism, Migration and Political Theory. Political Studies, 64 (1): 42-59. https://doi.org/10.1111/1467-9248.12167.

Sager, Alex (2017): Immigration Enforcement and Domination: An Indirect Argument for Much More Open Borders. Political Research Quarterly, 70 (1): 42-54. https://doi.org/10.1177/1065912916680036.

Sager, Alex (2018): Toward a Cosmopolitan Ethics of Mobility. https://doi.org/10.1007/978-3-319-65759-2. 
Sandel, Michael J. (1998): Democracy's discontent: America in search of a public philosophy. Cambridge, Belknap Press of Harvard Univ. Press.

Shachar, Ayelet (2009): The Shifting Border of Immigration Regulation. 30 Mich. J. Int'l L. 809. http:// repository.law.umich.edu/mjil/vol30/iss3/9.

Shachar, Ayelet (2016): Selecting By Merit. In: S. Fine-L. Ypi (szerk.): Migration in Political Theory, 175202. https://doi.org/10.1093/acprof:oso/9780199676606.003.0009.

Simpson, Thomas (2017): The Impossibility of Republican Freedom. Philosophy \& Public Affairs, 45 (1): 27-53. https://doi.org/10.1111/papa.12082.

Skinner, Quentin (1997): Liberty Before Liberalism.

Skinner, Quentin (2002): Visions of Politics: Renaissance Virtues (Vol. 2). Cambridge, Cambridge University Press.

Skinner, Quentin (2008): Hobbes and Republican Liberty. Cambridge, New York, Cambridge University Press.

Skinner, Quentin (2010): On the Slogans of Republican Political Theory. European Journal of Political Theory, 9 (1): 95-102. https://doi.org/10.1177/14748855109349407.

Thomas, Christopher A. (2015): "Globalising Sovereignty"? Pettit's Neo-Republicanism, International Law, And International Institutions. The Cambridge Law Journal, 74 (3): 568-591. https://doi. org/10.1017/S0008197315000707.

Thompson, M. J. (2013): Reconstructing Republican Freedom: A Critique of the Neo-Republican Concept of Freedom as Non-Domination. Philosophy \& Social Criticism, 39 (3): 277-298. https:/doi. org/10.1177/0191453712473081.

Tóth Szilárd János (2019): Szabadság és politikai részvétel a republikánus elméletben. Politikatudományi Szemle, XXVIII/2., 61-80.

Valentini, Laura (2012): Ideal vs. Non-ideal Theory: A Conceptual Map: Ideal vs Non-ideal Theory. Philosophy Compass, 7 (9): 654-664. https://doi.org/10.1111/j.1747-9991.2012.00500.x.

Viroli, Maurizio (1995): For Love of Country. Oxford, Oxford University Press.

Walzer, Michael (1984): Spheres of Justice: A Defense of Pluralism and Equality. New York, Basic Books.

Weinstock, Daniel-Nadeau, Christian (2012): Republicanism: History, Theory and Practice.

Wellman, Christopher (2008): Immigration and Freedom of Association. Ethics, 119 (1): 109-141. https:// doi.org/10.1086/592311.

Wellman, Christopher H. (2016): Freedom of Movement and the Rights to Enter and Exit. In: S. Fine-L. Ypi (szerk.): Migration in Political Theory, 80-102. https://doi.org/10.1093/acprof:oso/9780199676606. 003.0005.

Wellman, Christopher-Cole, Phillip (2011): Debating the Ethics of Immigration: is There a Right to Exclude? Oxford, Oxford University Press.

Wilcox, Shelley (2009): The Open Borders Debate on Immigration. Philosophy Compass, 4 (5): 813-821. https://doi.org/10.1111/j.1747-9991.2009.00230.x.

Wimmer, Andreas-Glick Schiller, Nina (2002): Methodological Nationalism and Beyond: Nation-State Building, Migration and the Social Sciences. Global Networks, 2 (4): 301-334. https://doi. org/10.1111/1471-0374.00043.

Wimmer, Andreas-Glick Schiller, Nina (2003): Methodological Nationalism, the Social Sciences, and the Study of Migration: An Essay in Historical Epistemology. International Migration Review 37(3): 576-610. https://doi.org/10.1111/j.1747-7379.2003.tb00151.x. 